\title{
Analysis and therapeutic schedule of the postoperative recurrence of bone tuberculosis
}

\author{
Lei Yang ${ }^{1}$ and Zhonghe Liü $2^{2}$
}

\begin{abstract}
Objective: The present study aims to analyze the main reasons that lead to the failure of bone tuberculosis (TB) surgery and the efficacy of reoperation.

Methods: A total of 3,000 cases of bone TB patients were examined retrospectively. Of these, 180 cases had recurrence, including 135 cases of spinal TB and 45 cases of limb TB. Preoperative indicators of duration of anti-TB chemotherapy, nutritional conditions, temperature conditions and erythrocyte sedimentation rate, and medication time of postoperative and recurrence were statistically analyzed.

Results: Of all 180 cases with reoperation, 176 cases were cured, and four paralyzed patients were symptomatically improved. The causes of postoperative recurrence of bone TB were relatively complex. Efficacy of reoperation was evaluated. Shorter chemotherapy duration, long-term illness, poor health, a higher body temperature, and an accelerated ESR are likely to increase the risk of recurrence.
\end{abstract}

Conclusions: Given the operation failure, careful analysis of the failure reasons and the targeted reoperation can obtain satisfactory results, thereby avoiding the failure of the initial surgery.

Keywords: Bone tuberculosis, Recurrence, Reoperation, Therapeutic schedule

\section{Introduction}

Tuberculosis (TB), which is one of the major infectious diseases in the world today, has caused a huge threat to human health. About one third of the human population is infected with mycobacterium TB, with about 800 million new infections and up to two million deaths caused by TB each year. With the rapid growth of the global population, the acceleration of the population flow, and the human immunodeficiency virus (HIV) infection, morbidity of TB has been increasing every year [1-3]. In addition, the threat of drug-resistant TB is increasing. Various clinical resistances to first- and second-line anti-TB drugs have been observed among TB patients, and those with multi-drug resistant TB (MDR-TB) and extensively drug-resistant $\mathrm{TB}$ (XDR-TB) are also progressive [4-6]. Lung TB accounts for the vast majority of the proportion of drug-sensitive and drug-resistant TB. Consequently, TB research has focused on lung $\mathrm{TB}$, while those on bone TB are fewer. Bone TB is a chronic disease, which

\footnotetext{
* Correspondence: zheliuc@126.com

${ }^{2}$ Department of Orthopedics, The First Affiliated Hospital of Xinxiang Medical University, Weihui, Henan 453100, China

Full list of author information is available at the end of the article
}

is difficult to treat and easy to recur, and its morbidity has increased in the past 10 years $[7,8]$.

Drugs and surgery are the main treatments for bone TB. A certain recurrence rate occurs after surgery. In this study, 180 bone TB patients who underwent reoperation were studied to provide a basis for clinical treatment of bone TB.

\section{Materials and methods \\ Clinical data}

Of all 3,000 cases of bone TB in the First Affiliated Hospital of Xinxiang Medical College from January 2005 to December 2011, 180 cases had recurrence, of which 108 were male and 72 female. Their ages ranged from 23 to 63 years, and average age was $40 \pm 10.2$ years. Spinal TB was found in 135 cases and limb TB in 45 cases. Local excision, decompression, bone grafting, and internal fixation, as well as compression arthrodesis were performed as the initial surgery. This study was conducted in accordance with the declaration of Helsinki. This study was conducted with approval from the Ethics Committee of the First Affiliated Hospital of Xinxiang Medical University 
Table 1 Influence of preoperative anti-TB chemotherapy on recurrence of bone tuberculosis

\begin{tabular}{lcccc}
\hline $\begin{array}{l}\text { Duration of } \\
\text { preoperative anti-TB } \\
\text { chemotherapy (week) }\end{array}$ & $\begin{array}{c}\text { Spinal } \\
\text { tuberculosis } \\
(\boldsymbol{n})\end{array}$ & $\begin{array}{c}\text { Limb } \\
\text { tuberculosis } \\
(\boldsymbol{n})\end{array}$ & Total & $\begin{array}{c}\text { Ratio } \\
(\%)\end{array}$ \\
\hline 1 & 96 & 34 & 130 & 72.2 \\
$1 \sim 2$ & 23 & 8 & 31 & 17.2 \\
$2 \sim 4$ & 17 & 2 & 19 & 10.6 \\
\hline
\end{tabular}

(permit number: 20060828001). Written informed consent was obtained from all participants.

\section{Data analysis}

Indicators of 180 patients with bone TB were analyzed retrospectively. These indicators included duration of anti-TB chemotherapy, nutritional conditions, body temperature, and erythrocyte sedimentation rate (ESR) before operation, as well as medication time and recurrence after operation.

\section{Operation methods}

Routine physical examination and blood, urine, and liver function tests were carried out before the surgery to learn the medical history of and causes for reoperation of the patients. Through conventional anti-TB treatment, surgery can be performed when ESR and C-reactive protein decreased. Effective preoperative communication between doctors and patients was necessary for the establishment of trust with each other. Additionally, sufficient amount of blood was essential for surgical bleeding.

Therapeutic schedules were made in accordance with the causes for reoperation and their specific conditions. Simple local excision or combined decompression, bone grafting, and internal fixation were chosen for spinal TB, whereas simple local excision or combined compression arthrodesis for limb TB. The sequestra, necrotic tissue, invaded intervertebral disc, and pus were cleared to the greatest extent. Supplementary blood was administered according to blood loss in patients during surgery.

The recovery status and supply of nutrients of patients, especially neurotrophic supply, and traits of the drainage were taken into intensive care and postoperative surveillance for timely targeted treatment.

Table 2 Influence of postoperative medication on recurrence of bone tuberculosis

\begin{tabular}{lcccc}
\hline $\begin{array}{l}\text { Duration of } \\
\text { postoperative } \\
\text { medication (month) }\end{array}$ & $\begin{array}{c}\text { Spinal } \\
\text { tuberculosis } \\
(\boldsymbol{n})\end{array}$ & $\begin{array}{c}\text { Limb } \\
\text { tuberculosis } \\
(\boldsymbol{n})\end{array}$ & \begin{tabular}{c} 
Total \\
\hline 6
\end{tabular} & $\begin{array}{c}\text { Ratio } \\
(\%)\end{array}$ \\
\hline 8 & 45 & 22 & 67 & 37.2 \\
12 & 67 & 19 & 86 & 47.8 \\
\hline
\end{tabular}

Table 3 Influence of body temperature on recurrence of bone tuberculosis

\begin{tabular}{lcccc}
\hline $\begin{array}{l}\text { Body } \\
\text { temperature }\end{array}$ & $\begin{array}{c}\text { Spinal } \\
\text { tuberculosis }(\boldsymbol{n})\end{array}$ & $\begin{array}{c}\text { Limb } \\
\text { tuberculosis }(\boldsymbol{n})\end{array}$ & Total & $\begin{array}{c}\text { Ratio } \\
(\%)\end{array}$ \\
\hline Normal & 37 & 12 & 49 & 27.2 \\
$37^{\circ} \mathrm{C} \sim 37.4^{\circ} \mathrm{C}$ & 48 & 15 & 63 & 35.0 \\
$37^{\circ} \mathrm{C} \sim 38^{\circ} \mathrm{C}$ & 42 & 17 & 59 & 32.8 \\
Above $38^{\circ} \mathrm{C}$ & 28 & 1 & 29 & 16.1 \\
\hline
\end{tabular}

\section{Results}

Analysis of the causes of reoperations

Causes of reoperation were complex through the analysis of patients with bone TB. Generally, selective operation was carried out after 4 weeks of anti-TB chemotherapy. Of all the patients, $72.2 \%$ received operations after 1 week of administration, $17.2 \%$ in 2 weeks, and $10.6 \%$ in 4 weeks, demonstrating that the risk of recurrence increased with shortened chemotherapy duration. Of all the patients, 85.0\% were administered anti-TB chemotherapy for less than 1 year after operation, demonstrating that the risk of recurrence increased with shorter postoperative chemotherapy duration. Higher body temperature was found in $72.8 \%$ of the cases, which demonstrated that the risk of recurrence increased with a higher temperature. An accelerated ESR was found in $76.7 \%$ of the patients, thereby demonstrating that the risk of recurrence was related with an accelerated ESR (Tables 1, 2, 3, 4).

Long-term illness, food preference, and poor health were likely to increase the risk of recurrence. Bone destruction accounted for $8.8 \%$ of all kinds of recurrent manifestations, abscess in $74.4 \%$, and fistula in $16.7 \%$, demonstrating that cold abscess was more common (Tables 5 and 6).

\section{Result of reoperation}

A total of 180 patients underwent reoperation. The preoperative factors included careful analysis of the causes and the cautious selection of the operation time. Corrosion near the vertebral edge, annulus fibrosus in the intervertebral disc, and residual TB products in the contralateral lesion beyond direct vision were carefully removed. With reoperation, 176 cases were cured, and four paralyzed patients were symptomatically improved.

Table 4 Influence of ESR on recurrence of bone tuberculosis

\begin{tabular}{lcccc}
\hline ESR & $\begin{array}{c}\text { Spinal } \\
\text { tuberculosis }(\boldsymbol{n})\end{array}$ & $\begin{array}{c}\text { Limb } \\
\text { tuberculosis }(\boldsymbol{n})\end{array}$ & Total & Ratio (\%) \\
\hline Accelerated & 113 & 25 & 138 & 76.7 \\
Normal & 22 & 20 & 42 & 23.3 \\
\hline
\end{tabular}


Table 5 Nutritional status

\begin{tabular}{|c|c|c|c|c|}
\hline Nutritional status & $\begin{array}{c}\text { Spinal } \\
\text { tuberculosis } \\
(n)\end{array}$ & $\begin{array}{c}\text { Limb } \\
\text { tuberculosis } \\
(n)\end{array}$ & Total & $\begin{array}{c}\text { Ratio } \\
(\%)\end{array}$ \\
\hline Abstention from meat & 118 & 32 & 150 & 83.3 \\
\hline Abstention from vegetables & 17 & 13 & 30 & 16.7 \\
\hline
\end{tabular}

\section{Discussion}

The recurrence of bone TB was related to many factors through the treatment of 180 recurrent patients. The anti-TB chemotherapy of quadruple or quintuple antiTB drugs was administrated as early as possible, and efficacy was observed. Invalid anti-TB drugs should promptly be adjusted. In case of liver function damage, the dosage was timely reduced in patients with poor health, old age, and children after 5 to 7 days of treatment with high-dose anti-TB drugs $[9,10]$. Surgical treatment without anti-TB chemotherapy was prohibited for extremely high risk of recurrence. Operation was recommended after 4 weeks of anti-TB treatment, which was prolonged on the condition that temperature was above $38^{\circ} \mathrm{C}$ and ESR was above $50 \mathrm{~mm} / \mathrm{h}$ [11].

The eating habits of the persons were adjusted to a high-calorie, high-protein, high-vitamin, high-carbohydrate, and appropriate fat food. Most patients have lost their appetite for meat, and a few cases had no appetite for vegetables. More beef, lamb, pork, fish, fresh vegetables, and fruits were beneficial for the chronic wasting disease TB [12,13].

Emotional adjustment in patients was also important for patients with depression and irritability due to longterm illness and poverty. Patient explanation for the cause, diagnosis, treatment, and prevention of TB was significant for confidence enhancement and better cooperation among patients.

Careful analysis of the condition of patients and favorable surgical schedule were taken prior to surgery. Sequestra, invaded intervertebral disc, necrotic tissue, corrosion near the vertebral edge, unilateral local excision, contralateral abscess, gravitation abscess (if it was present), and annulus fibrosus in the intervertebral disc were all thoroughly removed without any residue. Thoroughness of the surgery is the key factor that influences the success of TB treatment $[14,15]$.

In conclusion, $\mathrm{TB}$ is characterized by difficulty of treatment and easy recurrence, yet bone TB can be cured by

Table 6 Symptoms of recurrence

\begin{tabular}{lcccc}
\hline $\begin{array}{l}\text { Symptoms } \\
\text { of recurrence }\end{array}$ & $\begin{array}{c}\text { Spinal } \\
\text { tuberculosis } \\
(\boldsymbol{n})\end{array}$ & $\begin{array}{c}\text { Limb } \\
\text { tuberculosis } \\
(\boldsymbol{n})\end{array}$ & Total & $\begin{array}{c}\text { Ratio } \\
(\%)\end{array}$ \\
\hline Bone destruction & 9 & 7 & 16 & 8.8 \\
Abscess & 112 & 22 & 134 & 74.4 \\
Fistula & 14 & 16 & 30 & 16.7 \\
\hline
\end{tabular}

initial surgery with improved success rate and targeted reoperation. Success rates were improved by the good emotional status of patients, systematic anti-TB chemotherapy and an appropriate time of surgery before operation, a thorough removal of the lesions without any sequestrum, and gravitation abscess in operation, coupled with regular as well as combined and adequate anti-TB chemotherapy after operation.

\section{Conclusion}

The causes of postoperative recurrence of bone TB were relatively complex. A careful analysis of the reasons and the targeted reoperations can obtain satisfactory results, thereby avoiding the failure of the initial surgery.

Competing interests

The authors declare that they have no competing interests.

Authors' contributions

$\mathrm{ZL}$ designed the study, and LY performed the study. ZL and LY analyzed the data and wrote the paper. Both authors read and approved the final manuscript.

\section{Acknowledgements}

We would like to acknowledge Prof. Wang Tianyun for the analysis and interpretation of data.

\section{Author details}

${ }^{1}$ School of Nursing, Xinxiang Medical University, Xinxiang 453003, China.

${ }^{2}$ Department of Orthopedics, The First Affiliated Hospital of Xinxiang Medical University, Weihui, Henan 453100, China.

Received: 4 May 2013 Accepted: 2 December 2013

Published: 17 December 2013

\section{References}

1. Orcau À, Caylà JA, Martínez JA: Present epidemiology of tuberculosis: prevention and control programs. Enferm Infecc Microbiol Clin Suppl 2011, $1: 2-7$.

2. Jassal MS, Bishai WR: Epidemiology and challenges to the elimination of global tuberculosis. Clin Infect Dis 2010, 50(Suppl 3):S156-S164.

3. Nahid P, Menzies D: Update in tuberculosis and nontuberculous mycobacterial disease 2011. Am J Respir Crit Care Med 2012, 185:1266-1270.

4. Taylor AB, Kurbatova EV, Cegielski JP: Prevalence of anti-tuberculosis drug resistance in foreign-born tuberculosis cases in the U.S. and in their countries of origin. PLoS One 2012, 7:e49355.

5. Maurya AK, Kant S, Nag VL, Kushwaha R, Dhole TN: Trends of anti-tuberculosis drug resistance pattern in new cases and previously treated cases of extrapulmonary tuberculosis cases in referral hospitals in northern India. J Postgrad Med 2012, 58:185-189.

6. Drobniewski F, Nikolayevskyy V, Balabanova Y, Bang D, Papaventsis D: Diagnosis of tuberculosis and drug resistance: what can new tools bring us? Int J Tuberc Lung Dis 2012, 16:860-870.

7. Garg RK, Somvanshi DS: Spinal tuberculosis: a review. J Spinal Cord Med 2011, 34:440-454

8. Lesić AR, Pesut DP, Marković-Denić L, Maksimović J, Cobeljić G, Milosević I, Atkinson HD, Bumbasirević M: The challenge of osteo-articular tuberculosis in the twenty-first century: a 15-year population-based study. Int J Tuberc Lung Dis 2010, 14:1181-1186.

9. Liu Y, Chen Y, Yang L, Zhou X, Wang C, Qi M, Yuan W: The surgical treatment and related management for post-tubercular kyphotic deformity of the cervical spine or the cervico-thoracic spine. Int Orthop 2012, 36:367-372.

10. Dai LY, Jiang LS, Wang YR, Jiang SD: Chemotherapy in anterior instrumentation for spinal tuberculosis: highlighting a 9-month three-drug regimen. World Neurosurg 2010, 73:560-564. 
11. Feng $L, Q u D B$, Jin DD, Chen JT: Observation of body temperature and erythrocyte sedimentation rate in spinal tuberculosis patients with anterior interbody autograft and internal fixation. Di Yi Jun Yi Da Xue Xue Bao 2002, 22:84-85.

12. Xiao L, Jiang Y, Tian Y, Li X, Yin Q, Liu Z, Han L, Fu J: Primary anterior focus debridement and bone autograft with internal fixation via transperitoneal approach for tuberculosis of lumbosacral junction. Zhongquo Xiu Fu Chong Jian Wai Ke Za Zhi 2009, 23:913-916.

13. Shen HL, Xia Y, Li P, Wang J, Han H: Arthroscopic operations in knee joint with early-stage tuberculosis. Arch Orthop Trauma Surg 2010, 130:357-361.

14. Zhang HQ, Li JS, Zhao SS, Shao YX, Liu SH, Gao Q, Lin MZ, Liu JY, Wu JH, Chen J: Surgical management for thoracic spinal tuberculosis in the elderly: posterior only versus combined posterior and anterior approaches. Arch Orthop Trauma Surg 2012, 132:1717-1723.

15. Wang $X T$, Zhou CL, Xi CY, Sun CL, Yan JL: Surgical treatment of cervicothoracic junction spinal tuberculosis via combined anterior and posterior approaches in children. Chin Med J (Engl) 2012, 125:1443-1447.

doi:10.1186/1749-799X-8-47

Cite this article as: Yang and Liu: Analysis and therapeutic schedule of the postoperative recurrence of bone tuberculosis. Journal of

Orthopaedic Surgery and Research 2013 8:47.

\section{Submit your next manuscript to BioMed Central and take full advantage of:}

- Convenient online submission

- Thorough peer review

- No space constraints or color figure charges

- Immediate publication on acceptance

- Inclusion in PubMed, CAS, Scopus and Google Scholar

- Research which is freely available for redistribution 